\title{
Neutrophil to Total Cell Ratio Measurement
}

National Cancer Institute

\section{Source}

National Cancer Institute. Neutrophil to Total Cell Ratio Measurement. NCI Thesaurus.

Code $C 98763$.

The determination of the ratio of neutrophils compared to total cells present in a sample.

The measurement may be expressed as a ratio or percentage. 